\title{
Damage Cost of Drying of Aflaj in the Sultanate of Oman
}

\author{
Slim Zekri ${ }^{1 *}$, Ayoub Fouzai ${ }^{2}$, Ali Naifer $^{3}$, and Tariq Helmi ${ }^{4}$ \\ ${ }^{1}$ Department of Natural Resource Economics, College of Agricultural and Marine Sciences \\ Sultan Qaboos University, P.O. Box 34, Al-Khod 123, Sultanate of Oman \\ ${ }^{2}$ Ecole Superieure d'Agriculture de Mograne, University of Tunis, Tunisia \\ ${ }^{3}$ SCET-Agri Tunisie, Tunisia \\ ${ }^{4}$ Ministry of Regional Municipalities and Water Resources, Sultanate of Oman

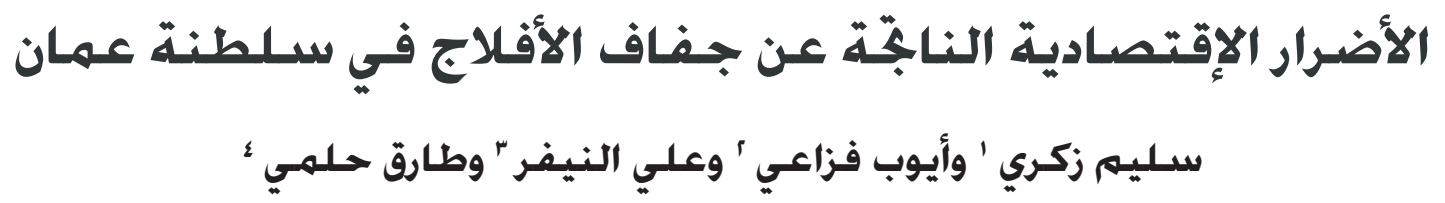

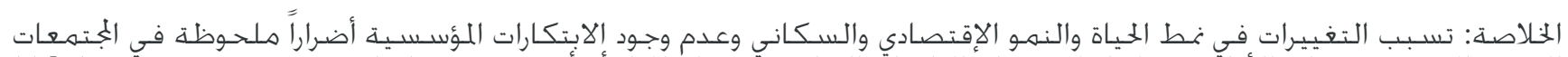

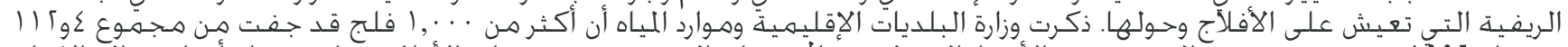

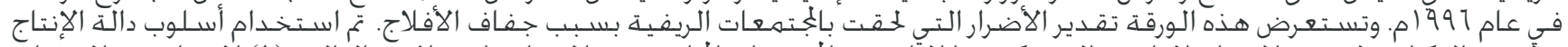

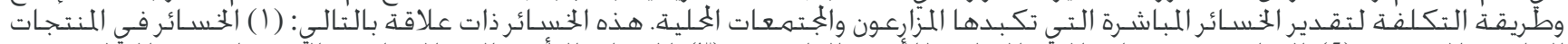

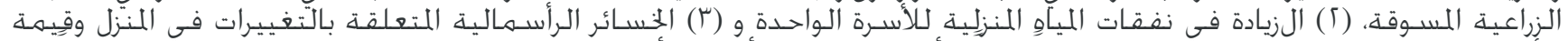

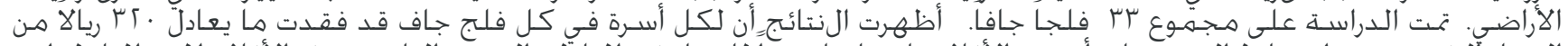

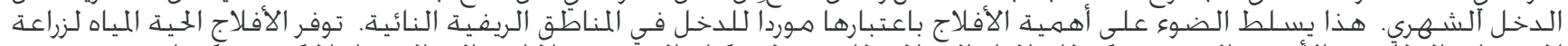

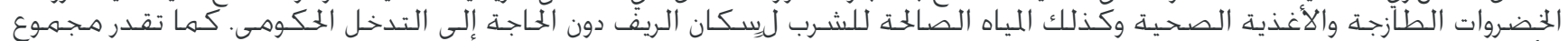

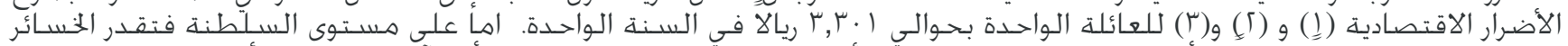

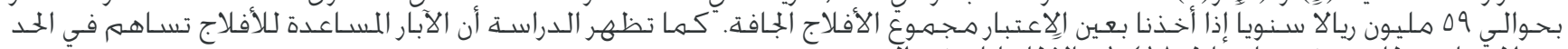

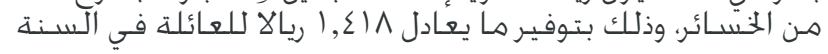

كلمات مفتـاحية: النقضض دخل المزارع ، المياه المنـزلية، نقـل المنازل ، القيمة المالية

ABSTRACT: Life style changes, population and economic growth, and lack of institutional innovations are causing noticeable damage to the rural communities living in and around Aflaj. The Ministry of Regional Municipalities and Water Resources (MRMWR) reported more than 1,000 dried-up Aflaj out of 4,112 in 1996. This paper presents an estimation of the damage caused to the rural communities due to Aflaj dry-up. The production function method and the cost based method are used to estimate the direct losses incurred by farmers and the local communities. These are related to (1) losses in marketed agricultural products, (2) increase in domestic water expenditures per household and (3) capital losses related to changes in house and land values. The study considered 33 dried-up Aflaj among the 1029 monitored by the MRMWR. Our results show that on average each family in the dried-up Falaj has lost an income equivalent of O.R 320 per month. This highlights the importance of Aflaj as an income generator in the remote rural areas. Live Aflaj provide fresh vegetables and healthy food as well as drinking water to the rural population without the need for governmental intervention. The contribution of the supporting wells, whenever provided by the MRMWR, is estimated at O.R 1,478 per family per year. On average the annual financial loss per family due to dry-up is estimated at O.R 3,301 per year. The total damage cost of dried-up Aflaj, at the Sultanate level, is estimated at more than O.R 59 million per year.

Keywords: Farmers' income losses, domestic water, housing relocation, present value.

\section{Introduction}

Groundwater quantity and quality are declining in the arid and semi-arid regions. Several externalities caused by groundwater depletion in these environments have been observed (Reddy, 2005 \& 2001). In many arid regions, several groundwater hydraulic structures have been used to drain out of the surface by gravity. These systems are referred to as Aflaj, Karez, Foggara, Qanat...etc. These “...ancient engineering technologies demonstrate long standing, sustainable use of water ... in extremely arid desert lands" (UNESCO, 2007). Groundwater over-exploitation, inadequate policies and the lack of maintenance of these infrastructures are causing their deterioration and consequent abandonment (Hussain et al., 2008).

Although Aflaj in Oman have persisted for hundreds of years, they are facing an unprecedented degradation in recent years as confirmed by flow measurements (Al-Ghafri, 2006; MRMEWR, 2006). A survey undertaken by the Ministry of 
Regional Municipalities and Water Resources (MRMWR, 2001) in 1996 has reported that more than 1,000 Aflaj out of 4,112 have dried-up Aflaj supply about 410 million $\mathrm{m}^{3} /$ year, representing $38 \%$ of Oman's fresh water, which satisfies part of domestic and agricultural demand in scattered rural areas (Norman et al., 1997; Zekri and Al-Marshudi, 2008). Aflaj constitute an integrated environment where thousands of people live, produce, consume and trade healthy fresh products. Lifestyle changes, population and economic growth, and lack of institutional innovations are causing noticeable damages to the rural communities living in and around these Aflaj.

All or most Aflaj are tapping the shallow alluvium aquifer, located at the open plain away from the mountainous area which constitutes the recharging area. A Falaj dries up whenever the water level at the mother well is lowered below the regional groundwater table. This usually happens as a result of over pumping the aquifer regardless of the recharge. The drilling of wells to support dried-up Aflaj in the affected areas, whenever possible, is a solution implemented by the government to counteract the damages to rural communities. However, long-term drought periods cause a regional lowering of the water table and negatively affect the efficiency of the supporting wells and the sustainability of the Aflaj communities.

To mitigate the effects of Aflaj deterioration the Omani government, through the MRMWR, supported 669 projects of Aflaj reparation and maintenance with a total cost of O.R 5.73 million (Al Sulaimani et al., 2007). However, these achievements were not enough to prevent Aflaj dry-up, whose major cause is groundwater over pumping. In fact, there is no scientific evidence of rainfall decline or change in rainfall intensity during the period 1974-2003 as shown by Kwarteng et al. (2009) eliminating thus the assumption of drought being the cause of dry-up. Although several studies have been undertaken regarding Aflaj irrigation systems, water resources (AlGhafri, 2006) and water markets (Zekri et al., 2006), the damage caused to the rural communities due to Aflaj dryup has not been estimated. Evaluating the damages caused to communities by Aflaj dry-up helps decision makers to implement appropriate policies to remedy and/or prevent it and to support public expenditures in repairing and maintaining some of the Aflaj.

The objective of this paper is to estimate the losses resulting from Aflaj dry-up with a focus on direct losses incurred by farmers at the local Falaj community. Farmers are the legal owners of the Falaj water (Zekri and AlMarshudi, 2008). The environmental as well as the social losses, are beyond the objective of this paper.

\section{Literature Review}

Estimates of damage cost due to natural resources degradation have been presented in a number of studies. Hussain et al. (2008) identified the benefits and costs of the Karez Ain-Zubaida rehabilitation project in Saudi Arabia without a quantitative estimation. The potential benefits are recreation, preservation of cultural-heritage, ecological and energy saving from pumping. The costs refer to tube-well owner's losses due to the reduction of pumping and the costs of rehabilitating, operating and managing the karez system. The authors stressed that rehabilitation of the karez is pre-conditioned by the ability to establish and implement a regulatory framework of water use and water rights' system. Total water pumping from private tube-wells should be halved. If this could be achieved then a sustainable direct social benefit of water estimated at O.R 16,900 per day will incur in the long term. According to Hussain et al. (2008) two types of costs were related to water resources degradation in the karez systems; on the one hand, indirect costs to the society as a cultural heritage loss, adverse environment impacts, loss of employment opportunities, loss of value related to tourism and associated economic activities. On the other hand, direct costs to private owners were identified as capital cost, operating and management cost, energy pumping and water transportation cost.

Reddy (2005) estimated the costs of groundwater depletion in India, using the public good and externalities framework. He estimated household income as a function of groundwater depth, total land owned and level of education. He then derived the costs of degradation and the resulting losses incurred at the household level. The author considered two cost categories; direct costs and indirect costs. The direct costs are replacement costs in the form of investment made in bore wells, sunk costs: capital loss due to drying up of open wells. The indirect costs are the losses in net return per acre and losses due to cropping pattern changes.

Howe and Goemans (2003) used an input-output model to estimate the losses of the irrigated area reduction due to water rights transfer from the South Plate and Arkansas Basins. Falls of agricultural production negatively affect agricultural input suppliers, agricultural output processors and financial institutions. The authors assumed five to ten years for reemployment of displaced labor, capital and land after water transfer has taken place. The study involved determination of the cropping pattern, crop yields and crop prices for the dried-up land, value of output losses that have been sold outside the subject areas and changes in payment to households, taxes and employment. The results were presented as net present value of losses by unit of water volume transferred, using a discount rate of five percent and assuming that the annual loss drops linearly to zero by the end of the designated study period.

\section{Methodology}

Various techniques have been developed to assess the economic impacts resulting from alterations of conditions influencing the flow of goods and services these assets provide. The literature of environmental valuation techniques provides various taxonomies of techniques developed and tested to measure the economic value 
Table 1. Methodology for the damage costs computation.

\begin{tabular}{lll}
\hline Type of damage & Description & Methodology \\
\hline Agricultural income loss & Marketed crop losses & Net factor income \\
& $\begin{array}{l}\text { Marketed livestock losses } \\
\text { Losses of household-consumption of agricultural } \\
\text { products }\end{array}$ & Market prices \\
\hline $\begin{array}{l}\text { Capital losses due to life conditions } \\
\text { degradation }\end{array}$ & $\begin{array}{l}\text { Relocation to another house (losing Falaj house and } \\
\text { cost of new building) }\end{array}$ & Relocation cost \\
\hline Increase water expenditures & $\begin{array}{l}\text { Value of agricultural land in Falaj } \\
\text { purpose }\end{array}$ & Market prices \\
\hline
\end{tabular}

of a broad range of environmental degradation. These techniques are classified as direct techniques and indirect techniques; (i) the direct techniques measure the monetary value of environmental services by looking to a surrogate market to infer individuals' preferences or by asking individuals to express their preferences. The travel cost method, hedonic price method and contingent valuation method are considered as a direct approach (Garrod and Willis, 1999); (ii) indirect techniques do not directly measure individual preferences. The indirect techniques don't provide accurate valuation information and welfare measures. Production function method and cost based valuation method are usually included in this technique.

The production function method values physical changes in production, caused by environmental change, using market prices for inputs and outputs. Changes in productivity are based on the relationship between environmental attributes and the output level of an economic activity. The money value estimates obtained with this approach should not be interpreted as the true value measure, but a proxy of the environmental change's ultimate welfare impacts.

Cost based methods measure the value of an environmental asset by the costs incurred in avoiding negative environmental impact. Costs are easy to quantify because they are based on market prices and use actual expenditures. However, the results may underestimate the true effects due to non-use value and non- material damages being excluded. Under this estimation technique, three distinct approaches can be designated; the averting behavior and relocation cost approach; the cost of illness and human capital approach and the restoration cost approach.

Two methods were used to estimate the damage resulting from Aflaj dry-up. The first one is the production function method where physical changes in production are valued using market prices for inputs and outputs. The second method is the cost based method which measures the value of an environmental asset, groundwater, by the costs incurred in avoiding negative impact of groundwater depletion. Within this later method the averting behavior and relocation cost approaches are used.

This paper estimates the losses resulting from Aflaj dry-up with an exclusive focus on direct losses incurred by farmers. The direct losses that will be estimated are shown in table 1 and are related to (1) losses in marketed agricultural products and family consumption, (2) increase in domestic water expenditures per household, (3) capital losses related to changes in house and land values (Fig. 1). The effects of Aflaj dry-up on the other economic activities such as input suppliers and food processors are negligible due to the subsistence nature of agricultural production irrigated by Aflaj.

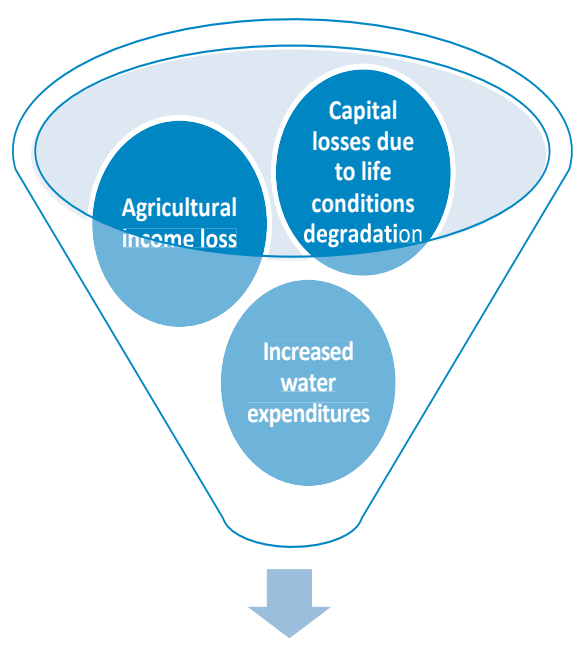

Total annual damage costs/family

Figure 1. Methodology for the estimation of the losses in dried-up Aflaj. 
Table 2. Value of marketed crop losses.

\begin{tabular}{lcccccccccc}
\hline & \multicolumn{3}{c}{ All Aflaj (N=191) } & \multicolumn{2}{c}{$\begin{array}{c}\text { Aflaj with supporting wells } \\
(\mathrm{N}=119)\end{array}$} & \multicolumn{2}{c}{$\begin{array}{c}\text { Aflaj without supporting wells } \\
(\mathrm{N}=72)\end{array}$} \\
\cline { 2 - 10 } & Min & Avg & Max & Min & Avg & Max & Min & Avg & Max \\
\hline Cropped area (ha) & 0.14 & 2.32 & 18.40 & 0.18 & 2.29 & 15.01 & 0.14 & 2.36 & 18.40 \\
$\begin{array}{l}\text { Gross margin crop losses } \\
\text { (O.R/ha/yr) }\end{array}$ & 108 & 585 & 1590 & 108 & 545 & 1538 & 143 & 651 & 1590 \\
\hline
\end{tabular}

\section{Case Study}

Aflaj represent an important source of water supply to a major part of the rural population in Oman. Degradation of the Aflaj systems influences the social and economic activities in the rural areas.

The study considered 33 dried-up Aflaj among the 1029 dried-up Aflaj monitored by the MRMWR (2001). A survey was undertaken during the period July-November 2008. A total of 205 farmers were interviewed and only 191 questionnaires were fully answered and then used for data analysis. Complementary information was obtained from local water authorities.

The survey was divided into four parts; household identification; living conditions around the Aflaj before and after water resource degradation; water resources in the Falaj before and after resource degradation and new costs of water supply for drinking and domestic purposes; agricultural losses due to Aflaj dry-up.

\section{Agricultural Losses}

Estimates of losses related to the ceasing of agricultural activity caused by Aflaj dry-up are based on average value of the agricultural marketed production per crop before and after the Aflaj dry-up. This value does not consider the production consumed by the family. These estimated values will be shown below. In fact, farmers were asked about the value of the gross margin before and after the Falaj dry-up. The gross margin implies the monetary transactions of the agricultural crops and does not include the family consumption. In some cases the government intervened by drilling tube wells, referred to as supporting wells, to support the local community, which allowed some agricultural crops to be partially grown. This required treating these two types of Aflaj separately in order to be able to measure the impact of government intervention to reduce the impact of dry-up. Thus, the results will be presented separately for Aflaj with supporting wells and Aflaj without supporting wells.

The gross margin provides an estimation of the direct loss to the farmer and local community. The total value of crop losses per household is estimated using the following equations.

\section{Marketed crop losses}

$$
G M X_{i \text { Lost }}=G M X_{i \text { After }}=G M X_{\text {iBefore }}
$$

Where,

$G M X_{i \text { Lost }}$ : Average Gross Margin loss per hectare per year of farm $X_{i}$;

$G M X_{i \text { Affer }}$ : Average Gross Margin (GM) per hectare per year of farm $X_{i}$, after dry-up;

$G M X_{i \text { Before }}$ : Average Gross Margin (GM) per hectare per year of farm $X_{i}$, before dry-up.

In the case of completely dried-up Aflaj, GM of farm $G M X_{i \text { After }}$ is equal to zero, thus the agricultural losses are equal to $G M X_{i \text { Before }}$. However, the existence of supporting wells in some Aflaj helped to maintain a few activities at the farm level. The same formula as in the case of dried-up Aflaj will be applied with the difference that $G M X_{i_{\text {Affer }}} \neq 0$.

The aggregation of losses per Falaj is estimated as follows:

$$
T G M X_{i \text { Lost }}=G M X_{i \text { Lost }} x T D A_{j}
$$

Where,

$T G M X_{i \text { Lost }}$ : Total loss of farm $\mathrm{X}_{i}$ GM for the whole Falaj;

$G M X_{\text {i Lost }}$ : Average farm $\mathrm{X}_{i} \mathrm{GM}$ in sampled farms;

$T D A_{j} \quad$ : Total dried up area (hectare) of the Falaj;

Results are presented in table 2 according to whether the Falaj benefitted from a supporting well or not. Results show that the average crop loss in Aflaj without supporting wells is $651 \mathrm{O} . \mathrm{R} / \mathrm{ha} / \mathrm{year}$ and is slightly higher than the loss in Aflaj with supporting wells which is estimated at 545 O.R/ha/year. Based on the field findings, the small difference in losses are due to: (i) the supporting wells are usually dug quite late after the damage has already occurred, (ii) the supporting wells' flows are considerably below the natural Aflaj flow as a result of regional groundwater depletion and (iii) the cropping pattern is more oriented to forage and annual crops rather than high value crops in order to avoid the risk related to the non- reliability of water supply.

\section{Marketed livestock losses}

The impact of Aflaj dry-up on livestock was less severe than the crop losses, because in several cases farmers were still able to maintain a minimum livestock activity based on grazing and buying of animal feed and concentrates 
Table 3. Value of marketed livestock losses.

\begin{tabular}{lccccccccc}
\hline & \multicolumn{3}{c}{ All Aflaj (N=191) } & \multicolumn{2}{c}{$\begin{array}{c}\text { Aflaj with supporting wells } \\
(\mathrm{N}=119)\end{array}$} & \multicolumn{3}{c}{$\begin{array}{c}\text { Aflaj without supporting wells } \\
(\mathrm{N}=72)\end{array}$} \\
\cline { 2 - 10 } & Min & Ave & Max & Min & Ave & Max & Min & Ave & Max \\
\hline $\begin{array}{l}\text { Cropped area (ha) } \\
\text { Livestock gross margin }\end{array}$ & 0.14 & 2.32 & 18.40 & 0.18 & 2.29 & 15.01 & 0.14 & 2.36 & 18.40 \\
losses (O.R/ha/yr) & 0 & 220 & 1159 & 0 & 201 & 1120 & 0 & 252 & 1159 \\
\hline
\end{tabular}

mainly in the case of Aflaj with supporting wells. The annual loss in net benefit of animal production is the difference between net benefit before and after dry-up, excluding the family consumption. The losses were then reported per hectare to allow aggregation of the results. A livestock gross margin for each activity was computed referring to the annual productivity, using prolificacy, mortality as well as reform rates. We proceeded by calculating the difference between the GM after and before Aflaj dry- up, which represents the annual livestock losses.

These losses are shown in table 3 and were estimated as follows:

$$
G M L S_{i \text { Affer }}-G M L S_{i \text { Before }}=G M L S_{i \text { Lost }}
$$

Where,

$G M L S_{i \text { After }}$ : Average GM per hectare per year of livestock activities after dry-up in surveyed farms;

$G M L S_{i \text { Before }}$ : Average GM per hectare per year of livestock activities before dry-up in surveyed farms;

$G M L S_{i \text { Lost }}$ : Average loss GM per hectare per year of livestock activities in surveyed farms.

In most sampled Aflaj we have observed four major animal activities; goats, sheep, cattle and camels. According to table 3, Aflaj without supporting wells have higher losses in terms of Gross Margin per hectare, estimated at $252 / \mathrm{ha} / \mathrm{yr}$ than those with supporting wells, estimated at $201 / \mathrm{ha} / \mathrm{yr}$. The minimal value of the losses (equal to zero) reflects either a zero loss or an absence of livestock activity in the farm.

\section{Household and Life Conditions}

\section{Household consumption}

Most of the farms around the Aflaj are small-scale properties and are considered as subsistence farms. The ceasing or reduction of agricultural and livestock production have had an adverse impact on households' vegetables, fruit and meat consumption. Aflaj households typically consume a considerable part of their production. After Aflaj dry-up, the households were obliged to buy the agricultural products from the market. In this section we account for that part of agricultural production which was destined for consumption and was not accounted for in the marketed agricultural production. The difference between a household's monthly expenditure for vegetables and fruit before and after a Falaj dry-up allows the researchers to estimate the family losses due to Aflaj drying up. This is considered as a lower-limit estimation because when farmers were the producers their opportunity cost was the wholesale price, while after the Falaj dry-up they are facing a retail price for the agricultural products. Since the retail prices are higher than the wholesale prices, thus the family demand of agricultural goods is negatively affected. Table 4 shows that on average a household spends O.R 551 per year to buy agricultural products that were previously produced at the farm level.

\section{Cost of house changing}

Moench (2007) reported that the changing of household location is considered as an adaptive response to drought and a strategy to mitigate the associated impacts. Our survey results showed that there are two types of adaptive

Table 4. Farm output household consumption losses.

\begin{tabular}{lccccccccc}
\hline & \multicolumn{3}{c}{ All Aflaj (N=191) } & \multicolumn{2}{c}{ Aflaj with supporting wells } & \multicolumn{3}{c}{$\begin{array}{c}\text { Aflaj without supporting } \\
\text { wells (N=72) }\end{array}$} \\
\cline { 2 - 10 } & Min & Ave & Max & Min & Ave & Max & Min & Ave & Max \\
\hline $\begin{array}{l}\text { Cropped area (ha) } \\
\begin{array}{l}\text { Household consumption } \\
\text { losses (per family/yr) }\end{array}\end{array}$ & 0.14 & 2.32 & 18.40 & 0.18 & 2.29 & 15.01 & 0.14 & 2.36 & 18.40 \\
& 24 & 551 & 1,800 & 48 & 542 & 1,800 & 24 & 567 & 1,800 \\
\hline
\end{tabular}


Table 5. Weighted average housing relocation losses in dried-up Aflaj in O.R/household.

\begin{tabular}{|c|c|c|c|c|c|c|c|c|c|}
\hline & \multicolumn{3}{|c|}{ All Aflaj ( N=191) } & \multicolumn{3}{|c|}{$\begin{array}{l}\text { Aflaj with supporting wells } \\
\qquad(\mathrm{N}=119)\end{array}$} & \multicolumn{3}{|c|}{$\begin{array}{l}\text { Aflaj without supporting wells } \\
\qquad(\mathrm{N}=72)\end{array}$} \\
\hline & Min & Ave & Max & Min & Ave & Max & Min & Ave & Max \\
\hline Average family size & 1 & 11 & 40 & 1 & 11 & 40 & 1 & 11 & 32 \\
\hline $\begin{array}{l}\text { Housing relocation } \\
\text { losses }\end{array}$ & 9807 & 31813 & 142920 & 11407 & 34836 & 142920 & 9807 & 23120 & 55502 \\
\hline $\begin{array}{l}\text { Weight (number of } \\
\text { houses relocated/total } \\
\text { Falaj houses) }\end{array}$ & & $(16 \%)$ & & & $(19 \%)$ & & & $(11 \%)$ & \\
\hline $\begin{array}{l}\text { Weighted housing } \\
\text { relocation losses (per } \\
\text { household) }\end{array}$ & 1569 & 5090 & 22867 & 2167 & 6618 & 27155 & 1079 & 2543 & 6105 \\
\hline $\begin{array}{l}\text { Average Falaj } \\
\text { household number }\end{array}$ & & 38 & & & 45 & & & 29 & \\
\hline $\begin{array}{l}\text { Aggregated housing } \\
\text { relocation losses (per } \\
\text { Falaj) }\end{array}$ & 59622 & 193420 & 868946 & 97515 & 297810 & 1221975 & 31291 & 73747 & 177045 \\
\hline
\end{tabular}

behaviour dictated by access to domestic water. In fact, if the initial house location is on the village periphery, access to domestic and drinking water is ensured through water tankers avoiding the displacement or rebuilding of another house. However, if the house is in the middle of the fields, with narrow access paths, water provisioning becomes impractical and relocation becomes a necessity. The damage cost is calculated as the sum of the lost value of the Falaj house and the cost of building a new house. The damage cost is only estimated for farmers who changed their houses due to the drought and degradation of living conditions at the Falaj. The first row of table 5 shows that the average loss, due to house relocation considering all Aflaj samples, as estimated at O.R 31,813. However, only $16 \%$ of the families were obliged to relocate their houses, consequently the weighted average cost of housing relocation is estimated at 5,090/family.

Housing losses were computed as follows:

$$
H L_{i=} F_{i}+\mathrm{NHC}_{i}
$$

Where,

$H L_{i} \quad$ : Average housing losses for surveyed household from sampled Aflaj;

$\mathrm{FHC}_{i}$ : Average value of abandoned Falaj house;

$\mathrm{NHC}_{i}$ : Building cost of new house due to Falaj dry-up.

\section{Cost of water for domestic and drinking purposes}

In normal conditions Aflaj represent the main water source for domestic and drinking purposes. After dry-up the households in Aflaj turn to use multiple sources of water of different qualities. Data collected from farmers have taken into account the difference between domestic and drinking purposes following Verhagen and Bhatt (2006). Farmers were asked to provide detailed costs of the water according to the uses and the sources. Four sources were considered, wells, water company, tankers and bottled water. The aggregated computation of domestic water losses due to Aflaj dry-up were estimated as below:

$$
T D U L=N\left[\begin{array}{l}
\left(\left(D O W C C_{i \text { Affer }}-D O W C C_{i \text { Before }}\right) \times P W C\right) \\
+\left(\left(D O W E C_{i \text { Affer }}-D O W E C_{i \text { Before }}\right) \times P W E\right) \\
+\left(\left(D O T A C_{i \text { Affer }}-D O T A C_{i \text { Before }}\right) \times P T A\right)
\end{array}\right]
$$

Where,

$T D U L$ : the total domestic water uses losses in the whole Falaj after dry-up;

$\mathrm{N} \quad$ : Total number of households leaving in sampled Falaj;

$P W C$ : Percentage of surveyed households using water from company to meet their domestic water uses;

$P W E$ : Percentage of surveyed households using wells to meet their domestic water uses;

PTA : Percentage of surveyed households using tankers to meet their domestic water uses;

PMI : Percentage of surveyed households using bottled water to meet their domestic water uses.

Results are shown in table 6. It is estimated that on average a family is spending a cost of O.R 328 per year for domestic water as a replacement cost against the water that was previously supplied freely by the falaj. Households at Aflaj without supporting wells spend 21 O.R/yr more than households at Aflaj with supporting wells. 
Table 6. Annual drinking water and domestic water losses per family.

\begin{tabular}{lccccccccc}
\hline & \multicolumn{3}{c}{ All Aflaj (N=191) } & \multicolumn{2}{c}{$\begin{array}{c}\text { Aflaj with supporting wells } \\
(\mathrm{N}=119)\end{array}$} & \multicolumn{3}{c}{$\begin{array}{c}\text { Aflaj without supporting wells } \\
(\mathrm{N}=72)\end{array}$} \\
\cline { 2 - 10 } & Min & Ave & Maxi & Min & Ave & Max & Min & Ave & Max \\
\hline Average Family size & 1 & 11 & 40 & 1 & 11 & 40 & 1 & 11 & 32 \\
\hline $\begin{array}{l}\text { Drinking water losses } \\
\text { (per family/yr) }\end{array}$ & 24 & 132 & 540 & 24 & 133 & 540 & 24 & 131 & 384 \\
$\begin{array}{l}\text { Domestic water losses } \\
\text { (per family/yr) }\end{array}$ & 24 & 202 & 600 & 24 & 191 & 600 & 36 & 221 & 540 \\
$\begin{array}{l}\text { Total water provisioning } \\
\text { losses (per family/yr) }\end{array}$ & 36 & 328 & 816 & 36 & 320 & 816 & 72 & 341 & 648 \\
\hline
\end{tabular}

Aflaj were the only water source for agriculture, drinking and domestic purposes in the past. However, after Afalaj dry-up, several water sources were needed. In most cases, two sources of water supply are observed; a good quality water for drinking purposes, and a lower quality water for domestic uses which is considerably cheaper. For this reason total water losses were presented according to their use. The average loss is estimated to about O.R 7,610 per Falaj per year for the domestic uses and O.R 7,369 per Falaj per year for drinking purposes. Although these losses are very similar in value terms, the volumes of water consumed for drinking and domestic uses are largely dissimilar.

Table 7 represents the annual value of water used for drinking and domestic purposes in all dried-up Aflaj $(1,029)$ at the Sultanate level. The figure shows that on an annual basis the total loss reached more than O.R 15 million. In other terms, the 1,029 dried up Aflaj used to provide farmers and their families with a volume of water worth more than O.R 15 million in the form of drinking and domestic water. Currently, these families who have lost their water from Aflaj spend O.R 15 million to buy water for domestic and drinking purposes. The economic loss to the national community is even higher due to the fact that in most cases the water price is subsidized and does not reflect the real economic cost of water paid by the society as a whole to supply water to users.

\section{Agricultural Land Value Change in Aflaj}

Given the desert climate and low rainfall in Oman, all agricultural activities depend on irrigation. Consequently, Aflaj dry-up should result in a loss in the value of agricultural land as it is no longer considered a productive asset. To estimate the change in value of agricultural land, we asked farmers about the land value before and after Aflaj dry-up. Farmers who were not involved in land transactions found some difficulty in answering the question. The damage due to Aflaj dry-up is estimated as the difference between the land value before and the value after Aflaj dry-up. Another variable that affects land value is inflation, however until 2005 inflation in Oman was very low and close to zero. Thus we assume that the inflation effect on land price is negligible. Another variable that does affect land price is the change of its

Table 7. Annual domestic and drinking water losses in dried-up Aflaj.

\begin{tabular}{|c|c|c|c|c|c|}
\hline Region & $\begin{array}{c}\text { Losses for } \\
\text { domestic water per } \\
\text { (Falaj (/per yr }\end{array}$ & $\begin{array}{c}\text { Losses for drinking } \\
\text { water per Falaj } \\
\text { ((per yr }\end{array}$ & $\begin{array}{c}\text { Total water losses } \\
\text { per Falaj } \\
\text { (per yr) }\end{array}$ & $\begin{array}{c}\text { Number of } \\
\text { dried-up Falaj }\end{array}$ & $\begin{array}{c}\text { Total water losses } \\
\text { in dried-up Aflaj } \\
\text { ((per yr }\end{array}$ \\
\hline Al Buraimi & 0 & 11,280 & 11,280 & -- & -- \\
\hline Dakhliya & 11,386 & 6,436 & 17,822 & 249 & $4,437,616$ \\
\hline Dhahirah & 5,166 & 14,901 & 20,067 & 243 & $4,876,364$ \\
\hline North Batinah & 6,924 & 9,499 & 16,424 & 352 & $5,781,131$ \\
\hline Sharqiyah & 7,501 & 5,067 & 12,568 & 185 & $2,325,046$ \\
\hline Total & 7,610 & 7,368 & 14,977 & 1,029 & $15,411,648$ \\
\hline
\end{tabular}


Table 8. Land value changes.

\begin{tabular}{|c|c|c|c|c|c|c|c|c|c|}
\hline & \multicolumn{3}{|c|}{ All Aflaj sample $(\mathrm{N}=191)$} & \multicolumn{3}{|c|}{$\begin{array}{l}\text { Aflaj with supporting wells } \\
\qquad(\mathrm{N}=119)\end{array}$} & \multicolumn{3}{|c|}{$\begin{array}{l}\text { Aflaj without supporting wells } \\
\qquad(\mathrm{N}=72)\end{array}$} \\
\hline & Min & Ave & Max & Min & Ave & Max & Min & Ave & Max \\
\hline $\begin{array}{l}\text { Land value decrease } \\
\text { (/ha) }\end{array}$ & 0 & 11,279 & 65,238 & 0 & 10,762 & 42,857 & 0 & 11,880 & 65,238 \\
\hline $\begin{array}{l}\text { Land value Increase } \\
\text { (per ha) }\end{array}$ & $-54,762$ & $-15,223$ & -476 & $-54,762$ & $-16,071$ & -476 & $-30,952$ & $-12,194$ & $-1,190$ \\
\hline $\begin{array}{l}\text { Net result: increase/ } \\
\text { decrease (per ha) }\end{array}$ & $-54,762$ & 475 & 65,238 & $-54,762$ & $-2,655$ & 42,857 & $-30,952$ & 5,967 & 65,238 \\
\hline
\end{tabular}

status from agricultural land to urban land. Whenever agricultural land is converted to urban uses, the land value increases. In fact in some cases a Falaj dry-up allowed farmers to urbanize their lands or sell it for urban uses which resulted in an increase of its value. By law, Aflaj land and agricultural land could not be converted into urban land if a Falaj is still flowing and agricultural activity is possible. The change in monetary value takes negative values when there is increase in the land value as it is not a damage but rather a benefit. Table 8 shows that on average the net result for the agricultural land value is a loss of O.R 475 per hectare due to Aflaj dry-up. For those Aflaj which benefited from supporting wells the land value has actually increased as shown on the last row by O.R -2,655 per hectare. For Aflaj without supporting wells the net result was a decrease in land value of O.R 5,967 per hectare.

\section{Total Value of Losses per Family}

Table 9 summarizes the annual losses incurred by an average family due to Aflaj dry-up. These losses are monetary losses that the family used to receive (crop losses, livestock losses, and agricultural employment losses) or to avoid payment (household consumption of agricultural products and cost of new sources of water for domestic uses, housing relocation cost) as well as the changes in the value of the agricultural land due to the dry-up.

To be able to add together losses that occur yearly, such as the agricultural income losses and losses (or gains) that occur once in a lifetime, such as the cost of relocation to another house and the change in the land value, the concept of depreciation is used. Thus, the once-in-life losses are thus converted into an annual value at an interest rate of $5 \%$ over a period of 40 years. The total annual losses per family varied between O.R 3,301 for Aflaj with supporting wells and O.R 4,779 for Aflaj without supporting wells. Thus, the contribution of supporting wells on a yearly basis is estimated as the difference of the above figures and is around O.R 1,478 per family. The supporting wells helped reduce the damage on crop and livestock losses as well as on the household consumption. However, the supporting wells did not contribute significantly to the cost of domestic water consumption. Overall, the contribution of supporting wells, undertaken by the Ministry of Regional Municipalities and Water

Table 9. Losses per family in O.R per year.

\begin{tabular}{|c|c|c|c|}
\hline & $\begin{array}{l}\text { All sample } \\
(\mathrm{N}=191)\end{array}$ & $\begin{array}{c}\text { Aflaj with } \\
\text { supporting wells } \\
(\mathrm{N}=119)\end{array}$ & $\begin{array}{c}\text { Aflaj without } \\
\text { supporting wells } \\
(\mathrm{N}=72)\end{array}$ \\
\hline Crop losses & 1,357 & 1,248 & 1,536 \\
\hline Livestock losses & 510 & 460 & 595 \\
\hline Losses of household-consumption of agricultural products & 1,278 & 1,241 & 1,338 \\
\hline Annualized relocation costs & 297 & 386 & 148 \\
\hline New sources of water for domestic and/or drinking purposes & 328 & 320 & 341 \\
\hline Annualized change of agricultural land value & 64 & -354 & 821 \\
\hline Total annual loss per family & 3,835 & 3,301 & 4,779 \\
\hline
\end{tabular}


Table 10. Total annual losses in dried-up Aflaj.

\begin{tabular}{lccccccc}
\hline Region & $\begin{array}{c}\text { Number of } \\
\text { dried-up } \\
\text { Falaj }\end{array}$ & $\begin{array}{c}\text { Marketed } \\
\text { agricultural } \\
\text { losses }\end{array}$ & $\begin{array}{c}\text { Household } \\
\text { consumption } \\
\text { losses }\end{array}$ & $\begin{array}{c}\text { Drinking } \\
\text { \& domestic } \\
\text { water losses }\end{array}$ & $\begin{array}{c}\text { Annualized } \\
\text { housing } \\
\text { relocation } \\
\text { cost }\end{array}$ & $\begin{array}{c}\text { Annualized } \\
\text { land value } \\
\text { loss }\end{array}$ & $\begin{array}{c}\text { Total Annual } \\
\text { losses in } \\
\text { dried-up } \\
\text { Aflaj }\end{array}$ \\
\hline Dakhliya & 249 & 565,829 & $5,004,402$ & $4,437,616$ & $2,804,530$ & 161,938 & $12,974,315$ \\
Dhahirah & 243 & $3,738,889$ & $10,712,967$ & $4,876,364$ & $2,736,951$ & 158,035 & $22,223,206$ \\
Batinah & 352 & $2,640,472$ & $10,488,896$ & $5,781,131$ & $3,964,637$ & 228,924 & $23,104,060$ \\
Sharqiyah & 185 & 835,745 & $2,750,280$ & $2,325,046$ & $2,083,687$ & 120,315 & $8,115,073$ \\
Total & 1029 & $8,784,833$ & $22,576,621$ & $15,411,648$ & $11,589,805$ & 669,212 & $59,032,119$ \\
\hline
\end{tabular}

Resources, is quite significant. Considering the full Aflaj sample, regardless of presence of supporting wells, the annual family losses are estimated at O.R 3,835 equivalent to $\mathrm{O} / \mathrm{R} 320$ per month. This figure shows the importance of Aflaj in providing food, employment, drinking water and income to families located in remote areas. Thus protecting Aflaj, whenever possible, contributes to environmental as well as economic sustainability.

\section{Total Losses of Dried-Up Aflaj in the Sultanate}

Table 10 shows the total annual losses from dried-up Aflaj at the sultanate level. The total loss is estimated at O.R 59.03 million per year. Region wise, the Batinah region's annual loss from dry Aflaj is the highest loss and is estimated at O.R 23.1 million. Figure 2 shows the distribution of the losses at the sultanate level. The highest losses are incurred by the loss of agricultural and animal production for farmers' families consumption labeled as "household consumption losses" representing $38 \%$ of the total losses. Drinking and domestic water users' losses represent $26 \%$, and finally, the lost gross margin from marketed agricultural products represents $15 \%$. It is worth noting that the losses of drinking and domestic water are higher than the marketed agricultural products. This is mainly due to the fact that several families who used to live around the Aflaj used to benefit from them as a source of water for domestic and drinking purposes without being owners of land next to Aflaj. On average 38 families live in and around each Falaj. The agricultural land value loss represents only $1 \%$ of the total loss. This is due to the fact that most of the land has been converted to urban uses thus increasing its value and compensating the loss

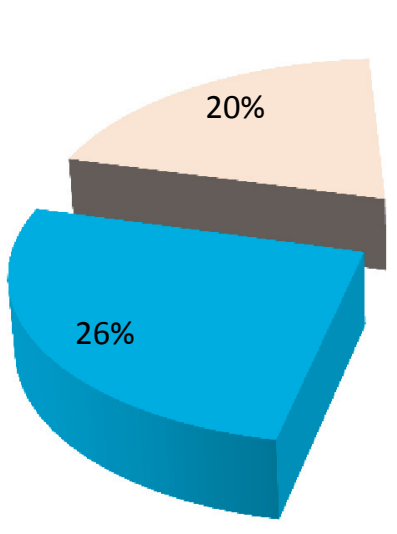

$1 \%$

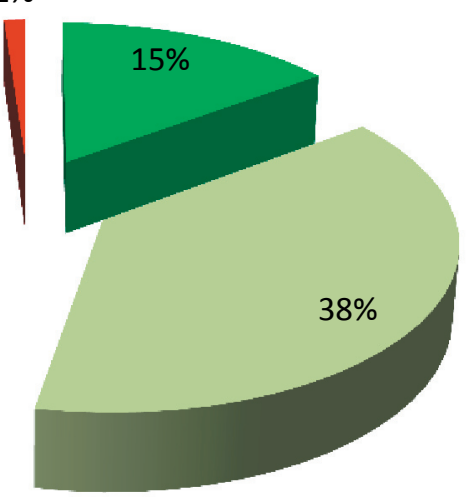

Agricultural Losses

Household consumption Losses

Drinking \& domestic water Losses

Housing relocation cost

Annualized land value loss

Figure 2. Annual losses in dried-up Aflaj. 
observed by some farmers who were unable to convert their land use.

\section{Conclusions}

Two methods have been used to estimate the damages resulting from Aflaj dry-up. The first one is the production function method where physical changes in production are valued using market prices for inputs and outputs. The second method is the cost based method which measures the value of an environmental asset, groundwater, by the costs incurred in avoiding negative impact. Within this latter method the averting behavior and relocation cost approach are used. Three types of impacts due to Aflaj dry-up have been observed and measured in this study. These are the agricultural income loss, household and life conditions degradation and finally the land value change.

The study considered 33 dried-up Aflaj among the 1029 dried-up Aflaj monitored by the MRMWR. A survey was undertaken during the period July-November 2008. A total of 205 farmers were interviewed and only 191 surveys were used for data analysis and loss computation. Complementary information was obtained from local water authorities.

The results have shown that on average a family owning land next to Aflaj has lost the equivalent of O.R 3,301 per year or O.R 320 per month. The monthly income from Aflaj represents more than treble the social security payment provided by government to needy families. The results show that Aflaj played and still play a major role as a sustainable income source in the remote rural areas and are thus a barrier against poverty. Farms provide fresh vegetables and healthy food to the rural population as well as drinking water without the need for any governmental intervention, in a sustainable way. On the other hand, $16 \%$ of the families living in and around Aflaj were obliged to relocate due to the dryness of Aflaj and lack of water. On average each of these families has spent 31,813 O.R as a cost of building a new house and the loss due to the abandoning of the old house located next to a Falaj.

The total losses in all dried-up Aflaj, at the Sultanate level, are estimated at more than O.R 59 million/yr with the losses in drinking and domestic water estimated at O.R 15 million/yr. In fact, Aflaj used to provide water for domestic purposes without the need to install a pipeline network to supply either groundwater or desalinated water from the coastal area. Our estimation of the losses related to domestic water is based on the extra cost incurred by families to buy water from new sources. This figure does not take into consideration the economic losses incurred by the government to supply domestic water to remote areas.

The major cause of Aflaj degradation and dry-up is the lax implementation of the law protecting the mother wells and aquifer storage. Some of the Aflaj studied have benefited from supporting wells drilled and equipped by the MRMWR. The supporting wells were found to have a positive impact mainly by reducing the damage on crop and livestock losses as well as on household consumption. The contribution of the supporting wells is estimated at O.R 1,478 per family per year. Taking into consideration the changes in land value and the cost of housing relocation those Aflaj which benefitted from supporting wells have had lower damage cost. The results have shown that the supporting wells contributed to limiting the damage to the families living in and around Aflaj but could not prevent it. Actually, the supporting wells draw water from the same shallow aquifer as Aflaj, and thus the volumes of water pumped could not provide enough relief to the population. Consequently, preventing Aflaj from drying up is a better solution than drilling supporting wells. Traditionally, farmers have always had plans to deal with natural drought or lack of rainfall by reducing the cropped area and limiting it to the perennial crops. However, when the dryness of Aflaj is caused by excess pumping, from illegal wells, farmers have to organize themselves and collaborate with the MRMWR to protect their rights.

Finally, in some cases, wells were drilled and the water use was diverted to other economic activities out of the Aflaj areas which might have resulted in higher income than the agricultural activity. Even though this might be true, the water diversion from one user to another user should have been done after agreements and payments to the farmers who own the water. Economic compensation should have taken place in such circumstances instead of an illegal transfer of water from Aflaj water owners to other users.

\section{Acknowledgements}

This research was financed by internal grant, IG/AGR/ ECON/05/01from Sultan Qaboos University. The research also benefitted from strong support of the Ministry of Regional Municipalities and Water Resources, Sultanate of Oman. The authors would like to thank especially Dr. Seif Al-Shaqai, DG Hamed Al-Hatmi, Eng. Saif AlAmri for their support to the project. Thanks also go to two reviewers and to Dr. Hemesiri Kotagama for their comments and suggestions which helped improve the paper considerably.

\section{References}

Al Sulaimani, Z.K., T. Helmi, and H. Nash. 2007. The social importance and continuity of Aflaj use in northern Oman. The $4^{\text {th }}$ Asian Regional Conference and $10^{\text {th }}$ International Seminar on Participatory Irrigation Management (PIM), 2-5 May 2007, Tehran, Iran.

Al-Ghafri, A. 2006. Aflaj's irrigation water demand/ supply ratio: two case studies. Agricultural and Marine Sciences - A Research Journal 11(Special Issue):85-92, Sultan Qaboos University, Sultanate of Oman.

Garrod, G. and K.G. Willis. 1999. Economic Valuation of the Environment: Methods and Case Studies, Chaltenham: Edward Elgar.

Howe, C.W. and C. Goemans. 2003. Water transfers and their impacts: lessons from three Colorado water 
markets. Journal of the American Water Resources Association 93:1055-1065.

Hussain, I., O.S. Abu-Rizaiza, M.A.A. Habib, and M. Ashfaq. 2008. Revitalizing a traditional dryland water supply system: the karezes in Afghanistan, Iran, Pakistan and the Kingdom of Saudi Arabia. Water International 33:333-349.

Kwarteng, A.Y., Atsu, S. D; Ganiga T. V. K. 2009. Analysis of a 27 year rainfall data (1977-2003) in the Sultanate of Oman. International Journal of Climatology 29:605-617.

MRMEWR (Ministry of Regional Municipalities, Environment and Water Resources). 2001. Aflaj Inventory Project Summary Report, the Sultanate of Oman, pp. 9-13.

MRMEWR. 2006. The Aflaj irrigation system of Oman. Nomination to the UNESCO World Heritage List. MRMEWR, Directorate General of Water Resources Affairs, Sultanate of Oman.

Moench, M. 2007. When the well runs dry but livelihood continues: adaptive responses to groundwater depletion and strategies for mitigating the associated impacts. CAB International 173-192.

Norman, W.R., W.H. Shayya, A.S. Al-Ghafri, and I.R McCann. 1997. Aflaj irrigation and on-farm water management in northern Oman. Irrigation and Drainage Systems 12:35-48,
Reddy, V.R. 2001. User valuation of renewable natural resource: a study of arid zone. In: User Valuation of Renewable Natural Resource: The User Perspective, V.R. Reddy (Editor). New York: Nova Science Publishers.

Reddy, V.R. 2005. Costs of resource depletion externalities: a study of groundwater overexploitation in Andhra Pradesh, India. Environment and Development Economics, 10:533-556. Cambridge University Press, UK.

UNESCO. 2007. Convention Concerning the Protection of the World Cultural and Natural; Heritage. WHC07/31.COM/2. Thirty-frist Session Christchurch, New Zealand, 23 June - 02 July 2007.

Verhagen, J. and M. Bhatt. 2006. Multiple Use of Water In Urban Areas - A Case Study in Bhuj, Gujarat, India (Final Report) June 2006.

Zekri, S., H. Kotagama, and H. Boughanmi. 2006. Temporary water markets in Oman. Agricultural and Marine Sciences - A Research Journal, 11(Special Issue):77-84. Sultan Qaboos University, Sultanate of Oman.

Zekri, S. and A. Al-Marshudi. 2008. A millenarian water rights system and water markets in Oman. Water International 33:350-360.

Received: November 6, 2012

Accepted: December 23, 2012 